\title{
Comparative Economics Analysis of Capsicum Cultivation under Protected and Open Field Conditions in Himachal Pradesh
}

\author{
Navneet Singh*, Ravinder Sharma and Ratika Kayastha \\ Department of Social Sciences, Dr Y S Parmar University of Horticulture \& Forestry, \\ Solan- 173 230, Himachal Pradesh, India \\ *Corresponding author
}

\section{A B S T R A C T}

\begin{tabular}{|l|}
\hline Key w o r d s \\
Capsicum \\
Cultivation, Open \\
Field Conditions, \\
Polyhouses \\
\hline Article Info \\
$\begin{array}{l}\text { Accepted: } \\
10 \text { July } 2020 \\
\text { Available Online: } \\
10 \text { August } 2020\end{array}$ \\
\hline
\end{tabular}

An attempt was made to study the comparative economics of capsicum cultivation under protected and open field conditions in Himachal Pradesh. Solan district was selected purposively on the basis of predominance of capsicum cultivation both under polyhouse and open field conditions. The primary data were collected by personal interviews of the selected farmers with the help of a specially designed schedule. Simple statistical tools like averages and percentages were used for processing the data. The overall findings of the study revealed the cost of production of capsicum under open conditions was Rs. 113878.48 per hectare at overall basis, varied between Rs. 118695.63 to Rs. 128959.10 per hectare among different farm categories. The cost of production of capsicum under protected conditions was Rs. 23570.64 and Rs. 40393.32 in $250 \mathrm{~m}^{2}$ and $500 \mathrm{~m}^{2}$ polyhouse respectively. Comparative economics analysis revealed that the cost of cultivation of capsicum under polyhouses were higher as compared to open field conditions by Rs. $20755.63 / 250 \mathrm{~m}^{2}$, Rs. $34769.90 / 500 \mathrm{~m}^{2}$. The net retunes from capsicum under protected conditions, were higher as compared to open field conditions Rs. $246.94 / 250 \mathrm{~m}^{2}$, Rs. $15792.38 / 500 \mathrm{~m}^{2}$. The results of the study revealed that the vegetable cultivation under polyhouses have contributed to the yield significantly.

\section{Introduction}

Capsicum (Capsicum annuum L. var. grossum Sendt) popularly known as Shmila Mirch belongs to the family Solanaceae. It is a popular vegetable in India. It is relatively a new entrant into our country and is native of Mexico with secondary centre of origin is Guatemala (Heiser and Smith, 1953). It is a high value vegetable crop which was brought to India by British people in $19^{\text {th }}$ century. In India, it is mainly cultivated in Himachal
Pradesh, U.P., J \& K, parts of West Bengal, Maharashtra and Karnataka (Chadha, 2005). It grows well in summer season in hills and cooler season in the plains. Capsicum is looked upon as luxury vegetable as its consumption is greater in and around the cities. The high market price is attributed to the heavy demand from urban consumers.

In India, Capsicum is grown in an area 30 thousand hectares with annual production of 172 thousand metric tonnes having 
productivity of 5.73 tonnes per hectare (NHB, 2016). Himachal Pradesh is a leading supplier of capsicum to the plains during summer and rainy season. The annual production of capsicum in Himachal Pradesh is 39.50 metric tonnes from an area of 2.24 thousand ha (NHB, 2016). The produce becomes offseason to the plains and fetches higher price to the vegetable growers (Joshi and Shukla, 1997). It is mainly grown in mid-hills (8001500 amsl.) of Solan, Sirmour, Bilaspur, Mandi and lower areas of district Shimla. However, productivity and quality of produce is low because of fluctuating environment prevalent during its cultivation in open. In addition, round-the year and off-season production of capsicum is not possible as it cannot be grown during winter months in open condition.

Capsicum, besides being a cash crop is also an important vegetarian food because of its high nutritional value particularly vitamin A (870 IU) and C (175 mg) per $100 \mathrm{~g}$ of edible portion. It also contains appreciable quantity of protein, calcium, thiamine, riboflavin and niacin (Mac Gillivary, 1961). It is believed to be used for the treatment of dropsy, colic, toothache, and cholera (Peirce, 1987).

Sweet pepper consumption in India is increasing now-adays due to increasing demand by urban consumers. There is a good demand for export too. The export market needs fruits with longer shelf life, medium size, tetra lobed fruits with an attractive dark colour, mild pungency and good taste. But, the supply is inadequate due to low productivity of the crop. There is a need to studies on economic aspects of capsicum production. Keeping in view of these aspects, the present study was a modest attempt to analyze the economics of capsicum production in Solan district of Himachal Pradesh.

\section{Materials and Methods}

The study was conducted in Solan district of Himachal Pradesh. This area was selected because of its significant contribution with respect to area and production of vegetable crops in the state and simultaneously providing fruitful employment to the families involved in vegetable cultivation. Multistage random sampling was adopted to select the ultimate sample of the respondents. There are 5 blocks in Solan district, among these 5 blocks Kandaghat and Solan were randomly selected. Ten villages from selected block were randomly selected. A total of 100 farmers (10 farmers from each village) were randomly taken as sample. A pre-tested structured interview schedule was prepared. Data was collected by personal interview method.

For the analysis of data the total vegetable growers were divided into four classes according to the size of their land holdings, $v i z$. , marginal (<1 ha), small (1-2 ha), medium (2-4 ha) and large farmers ( $>4$ ha). The distribution of the sampled vegetable growers under protected and open conditions according to their holding size.

\section{Analytical Tools}

\section{Cost of cultivation}

The cost of cultivation of vegetables crops was worked out by using various cost concepts defined below:

Cost $\mathrm{A}_{1}$

Cost $\mathrm{A}_{1}$ includes;

Cost of hired human labour

Cost of owned machinery

Cost of hired machinery

Cost of fertilizer 
Cost of manure

Cost of seed (owned / purchased)

Cost of plant protection chemicals

Land revenue

Depreciation of farm machinery, equipments and farm buildings Interest on owned working capital

Cost $A_{2}=$ Cost $A_{1}+$ Rent paid for leased in land

Cost $\mathrm{B}_{1}=$ Cost $\mathrm{A}_{1}+$ Interest on owned fixed capital assets excluding land

Cost $\mathrm{B}_{2}=$ Cost $\mathrm{B}_{1}+$ Rental value of own land (net of land revenue) + Rent paid for leased in land

Cost $\mathrm{C}_{1}=$ Cost $\mathrm{B}_{1}+$ Imputed value of family labour

Cost $\mathrm{C}_{2}=$ Cost $\mathrm{B}_{2}+$ Imputed value of family labour

Cost $C_{3}=$ Cost $C_{2}+10$ percent of cost $C_{2}$ on account of managerial function performed by the farmer.

\section{Income measures}

For working out profitability of vegetable cultivation in the study areas following income measures were worked out:

\section{Family labour income (FLI)}

It is the return to family labour (including management).

$$
\text { F.L.I. }=\text { Gross income }- \text { Cost } B_{2}
$$

\section{Net income (NI)}

It is the net profit after deducting all cost items i.e., variable and fixed costs from gross income.

$\mathrm{NI}=$ Gross income - Total $\operatorname{cost}\left(\operatorname{Cost} \mathrm{C}_{3}\right)$

\section{Farm business income (FBI)}

It is the disposal income out of the enterprise and is defined as:
$\mathrm{FBI}=$ Gross income - Cost $\mathrm{A}_{1}\left(\operatorname{cost} \mathrm{A}_{2}\right.$ in case of tenant operated land)

\section{Farm Investment Income (FII)}

FII $=$ Farm Business Income - Family Labour wages

\section{Break-even analysis}

The point at which the two curves, i.e., total cost curve and total revenue curve intersect is called the break-even point (BEP) which indicates the level of production at no profit no loss.

$\mathbf{B E P}=\frac{\mathbf{F}}{\mathbf{P}-\mathrm{V}}$

Where,

$\mathrm{F}=$ Fixed costs in Rs. per farm sizes

$\mathrm{P} \quad=\quad$ Price per $\mathrm{Kg}$

$\mathrm{V}=\quad$ Variable costs per $\mathrm{Kg}$

\section{Margin of safety}

Margin of safety is used in break-even analysis to indicate the amount of revenue/production that is above the breakeven point. Margin of safety indicates the amount of revenue/production that can be dropped before losses begin to be incurred. Higher margin of safety implies low risk.

Margin of safety $=$ Total Revenue at Output - Revenue at Break even point

Margin of safety $(\%)=\frac{\text { Revenue at Break even point }}{\text { Total Revenue at Output }} \times 100$

\section{Results and Discussion}

Cost and return structure of capsicum under protected and open conditions

Cost analysis play an important role in farm decision making, producers are concerned 
about the cost of production as it reflects the level of farm activity or an enterprise. Thus cost analysis helps in planning and implementing farm investment decisions. An attempt has been made in this section to analyse the cost and returns for different vegetable crops grown under protected and open conditions. Mainly capsicum was grown by the vegetable growers under protected and open conditions.

\section{Economics of Capsicum Production under Open Field Conditions}

\section{Cost of production}

Farm category wise cost of capsicum crop was estimated and results have been presented in Table 1.

The overall cost of cultivation of capsicum was estimated to be Rs. 113878.48 per hectare. Out of which cost A1, A2, B1, B2, C1, C2, and C3 were Rs. 60221.78, Rs. 60221.78, Rs. 61123.19, Rs. 73509.23, Rs. 91139.86, Rs. 103525.89, Rs. 103525.89 and Rs. 113878.48 respectively.

The cost of cultivation of capsicum in case of marginal farms was higher (Rs. 128959.10) as compared to large farms (Rs. 101657.19). It was Rs. 111533.48 on medium farms and Rs. 118695.63 on small farms.

Among different input operation on overall level, the per hectare cost was observed highest for FYM (Rs. 27233.33) followed by plant protection (Rs. 10814.44), hired labour (Rs. 9091.67), fertilizer (Rs. 3243.50), seed (Rs. 960.85), owned machinery (Rs. 1112.73) and hired machinery (Rs. 895.83).

The cost of owed human labour is the major contributor to the cost of cultivation of capsicum. Owed human labour on overall level was Rs. 30016.67. Owed human labour in case of marginal farms was highest (Rs.
46282.89) as compared to large farms (Rs. 19258.24), medium farms (Rs. 26388.89) and small farms (Rs. 36428.57).

The cost A1 in case of large farms was highest $(59.22 \%)$ as compared to marginal farms $(44.74 \%)$, small farms $(48.59 \%)$ and medium farms $(55.28 \%)$. There is no cost A2 because farmers used their owed land for cultivation of capsicum. Similar trend was found in cost B1 and cost B2 as in cost $\mathrm{A} 1$. The cost $\mathrm{C} 1$ in case of marginal farms was found highest $(81.30 \%)$ as compared to large farms $(78.72 \%)$, medium farms $(79.80 \%)$, and small farms $(80.47 \%)$. The cost $\mathrm{C} 3$ in case of marginal farms was higher (Rs. 128959.10) as compared to large farms (Rs. 101657.19), medium farms (Rs. 111533.48) and small farms (Rs. 118695.63).

\section{Returns from capsicum under open field conditions}

The information regarding the returns from capsicum per hectare basis is given in the table 2 . The results revealed that on an overall basis, yield of capsicum was 166.94 quintals per hectare. The yield was highest (181.91 qtls.) on marginal farms followed by small farms (169.84 qtls.), large farms (161.72 qtls.) and medium farms (156.06 qtls.) which indicated that gross return were found higher in marginal farms as compared to small, medium and large farms. It may due to better management practices and efficient use of resources by marginal farmers. The overall gross returns were Rs. 300500 per hectare.

The table revealed that farm business income which represents returns over cost A2, varied between Rs.345967.45 to Rs. 389592.86 with Rs. 374156.57 at overall basis. Family labour income which represents returns over cost B2, varied between Rs. 205903.90 to Rs. 256481.56 with Rs. 240278.22 at overall basis. Farm income (net income) varied between Rs. 169375.61 to Rs. 198475.11 with 
Rs. 186621.52 at overall basis. Farm investment income varied between Rs. 192862.50 to Rs. 223456.60 with Rs. 210261.55 at overall basis.

\section{Economics of Capsicum Production under Protected Conditions}

\section{Cost of production}

Polyhouse size wise cost of capsicum crop was estimated and results have been presented in Table 3. The major constituents of total cost were fixed cost with included depreciation on polyhouse equipments and interest on fixed capital. The cost of cultivation of capsicum was estimated to be Rs. 23570.64 in $250 \mathrm{~m}^{2}$ polyhouse. Out of which cost A1, A2, B1, B2, C1, C2, and C3 were Rs. 16581.01, Rs. 16581.01, Rs. 16603.20, Rs. 16912.85, Rs. 21118.20, Rs. 21427.85 and Rs. 23570.64 in $250 \mathrm{~m}^{2}$ polyhouse of capsicum cultivation. The cost of cultivation of capsicum was Rs. 40393.32 in $500 \mathrm{~m}^{2}$ polyhouse and cost $\mathrm{A} 1, \mathrm{~A} 2, \mathrm{~B} 1, \mathrm{~B} 2$, $\mathrm{C} 1, \mathrm{C} 2$, and C3 were Rs. 31161.09, Rs. 31161.09, Rs. 31205.47, Rs. 31824.78, Rs. 36101.90, Rs. 36721.20 and Rs. 40393.32. The cost of production has positive relation with the size of polyhouse. It can further be concluded from the analysis that polyhouse cultivation is capital intensive farming.

Among different input operation in $250 \mathrm{~m}^{2}$ polyhouse, the cost was observed highest for hired labour (Rs. 2292.86) followed by FYM (Rs. 1228.57), plant protection (Rs. 720.29), fertilizer (Rs. 289.96), seed (Rs. 53.75). Similar trend was found in case of $500 \mathrm{~m}^{2}$ polyhouse.

The cost of owed human labour is the major contributor to the cost of cultivation of capsicum under protected conditions. Owed human labour was Rs. 4515.00 and Rs. 4896.43 in $250 \mathrm{~m}^{2}$ and $500 \mathrm{~m}^{2}$ polyhouse respectively. Hired labour was found Rs.
1260.00 and Rs. 2292.86 in $250 \mathrm{~m}^{2}$ and 500 $\mathrm{m}^{2}$ polyhouse respectively.

\section{Returns from Capsicum under Protected Conditions}

The returns from capsicum production under different sizes of polyhouses were calculated and results have been presented in table 4 .

The results revealed that yield of capsicum were 14.20 quintals and 32.68 quintals in 250 $\mathrm{m}^{2}$ and $500 \mathrm{~m}^{2}$ polyhouse respectively. Gross returns were found Rs. 28400 and Rs. 65357.14 in $250 \mathrm{~m}^{2}$ and $500 \mathrm{~m}^{2}$ polyhouse respectively.

Farm business income which represents returns over cost A2, was Rs. 11818.99 in 250 $\mathrm{m}^{2}$ polyhouse while in $500 \mathrm{~m}^{2}$ polyhouse, it was found Rs. 34196.05. Family labour income which represents returns over cost B2, was Rs. 11487.15 and Rs. 33532.37 in $250 \mathrm{~m}^{2}$ and $500 \mathrm{~m}^{2}$ polyhouse respectively. Farm income (net income) was Rs. 4829.36 and Rs. 24963.82 in $250 \mathrm{~m}^{2}$ and $500 \mathrm{~m}^{2}$ polyhouse respectively. Farm investment income was Rs. 7303.99 and Rs. 29299.62 in $250 \mathrm{~m}^{2}$ and $500 \mathrm{~m}^{2}$ polyhouse respectively.

\section{Comparative economics of capsicum production under protected and open field conditions}

The finding obtained from comparative economic analysis of capsicum cultivation under protected and open field conditions are discussed here. Cost and returns of capsicum production under protected and open field conditions in $250 \mathrm{~m}^{2}$ and $500 \mathrm{~m}^{2}$ area, are elaborated and presented in table 5 .

In case of $250 \mathrm{~m}^{2}$, the cost of cultivation of capsicum under protected conditions was much higher (Rs. 23570.64) than open conditions (Rs. 2815.01). 
Table.1 Farm Category wise Cost of Capsicum under Open Field Conditions in Sampled Vegetable Growers (Rs./ha.)

\begin{tabular}{|c|c|c|c|c|c|c|}
\hline S.No. & Particulars & Marginal & Small & Medium & Large & Overall \\
\hline \multicolumn{7}{|l|}{ Cost A1 } \\
\hline & Human hired labour & 5674.34 & 7142.86 & 8939.39 & 12142.86 & 9091.67 \\
\hline & Owned machinery labour & 337.17 & 1164.02 & 1245.79 & 1319.44 & 1112.73 \\
\hline & Hired machinery labour & 2878.29 & 628.31 & 505.05 & 366.30 & 895.83 \\
\hline & Seed/plants & 992.43 & 946.30 & 939.81 & 937.50 & 960.85 \\
\hline & FYM & 27565.79 & 25608.47 & 28653.20 & 25531.14 & 27233.33 \\
\hline & Fertilizer & 4331.91 & 3646.30 & 2565.49 & 2965.57 & 3243.50 \\
\hline & Plant protection & 8444.08 & 8891.53 & 11609.43 & 12164.84 & 10814.44 \\
\hline & Depreciation & 6334.67 & 8562.18 & 5968.23 & 3516.06 & 5663.00 \\
\hline & Land Revenue & 6.00 & 6.00 & 6.00 & 6.00 & 6.00 \\
\hline & Interest on working capital & 1130.04 & 1080.63 & 1225.31 & 1247.12 & 1200.43 \\
\hline & Sub-total & 57694.72 & 57676.58 & 61657.71 & 60196.83 & 60221.78 \\
\hline & & $(44.74)$ & $(48.59)$ & $(55.28)$ & $(59.22)$ & $(52.88)$ \\
\hline \multicolumn{7}{|l|}{ Cost A2 } \\
\hline & Cost A1 & 57694.72 & 57676.58 & 61657.71 & 60196.83 & 60221.78 \\
\hline & Rental value of leased -in land & 0.00 & 0.00 & 0.00 & 0.00 & 0.00 \\
\hline & Sub-total & 57694.72 & 57676.58 & 61657.71 & 60196.83 & 60221.78 \\
\hline & & $(44.74)$ & $(48.59)$ & $(55.28)$ & $(59.22)$ & $(52.88)$ \\
\hline \multicolumn{7}{|l|}{ Cost B1 } \\
\hline & Cost A1 & 57694.72 & 57676.58 & 61657.71 & 60196.83 & 60221.78 \\
\hline & Interest on Fixed capital & 871.89 & 1413.93 & 961.45 & 574.53 & 901.41 \\
\hline & Sub-total & 58566.61 & 59090.51 & 62619.15 & 60771.35 & 61123.19 \\
\hline & & $(45.41)$ & $(49.78)$ & $(56.14)$ & $(59.78)$ & $(53.67)$ \\
\hline \multicolumn{7}{|l|}{ Cost B2 } \\
\hline & Cost B1 & 58566.61 & 59090.51 & 62619.15 & 60771.35 & 61123.19 \\
\hline & Rental value of land & 12386.03 & 12386.03 & 12386.03 & 12386.03 & 12386.03 \\
\hline & Rental value of leased -in land & 0.00 & 0.00 & 0.00 & 0.00 & 0.00 \\
\hline & Sub-total & 70952.65 & 71476.55 & 75005.19 & 73157.39 & 73509.23 \\
\hline & & $(55.02)$ & $(60.22)$ & $(67.25)$ & $(71.96)$ & $(64.55)$ \\
\hline \multicolumn{7}{|l|}{ Cost C1 } \\
\hline & Cost B1 & 58566.61 & 59090.51 & 62619.15 & 60771.35 & 61123.19 \\
\hline & Imputed value of family labour & 46282.89 & 36428.57 & 26388.89 & 19258.24 & 30016.67 \\
\hline & Sub-total & 104849.51 & 95519.09 & 89008.04 & 80029.59 & 91139.86 \\
\hline & & $(81.30)$ & $(80.47)$ & $(79.80)$ & $(78.72)$ & $(80.03)$ \\
\hline \multicolumn{7}{|l|}{ Cost C2 } \\
\hline & Cost B2 & 70952.65 & 71476.55 & 75005.19 & 73157.39 & 73509.23 \\
\hline & Imputed value of family labour & 46282.89 & 36428.57 & 26388.89 & 19258.24 & 30016.67 \\
\hline & Sub-total & 117235.54 & 107905.12 & 101394.08 & 92415.63 & 103525.89 \\
\hline & & $(90.91)$ & $(90.91)$ & $(90.91)$ & $(90.91)$ & $(90.91)$ \\
\hline \multicolumn{7}{|l|}{ Cost C3 } \\
\hline & Cost $\mathrm{C} 2$ & 117235.54 & 107905.12 & 101394.08 & 92415.63 & 103525.89 \\
\hline & Value of management input $(10 \%$ of cost $\mathrm{C} 2)$ & 11723.55 & 10790.51 & 10139.41 & 9241.56 & 10352.59 \\
\hline & Sub-total & 128959.10 & 118695.63 & 111533.48 & 101657.19 & 113878.48 \\
\hline & & $(100.00)$ & $(100.00)$ & $(100.00)$ & $(100.00)$ & $(100.00)$ \\
\hline
\end{tabular}


Table.2 Farm Category wise Return from Capsicum under Open Field Conditions in Sampled Vegetable Growers (Rs/ha.)

\begin{tabular}{|l|c|c|c|c|c|}
\hline Particulars & Marginal & Small & Medium & Large & Overall \\
\hline Yield of Capsicum (qtls) & 181.91 & 169.84 & 156.06 & 161.72 & 166.94 \\
\hline Gross Return & 327434.21 & 305714.29 & 280909.09 & 291098.90 & 300500.00 \\
\hline Farm Business Income & 269739.49 & 248037.70 & 219251.38 & 230902.07 & 240278.22 \\
\hline (Gross return - Cost A1) & & & & & \\
\hline Family Labour income & 256481.56 & 234237.74 & 205903.90 & 217941.51 & 226990.77 \\
\hline (Gross return - Cost B2) & & & & & \\
\hline Farm Income (net income) & 198475.11 & 187018.65 & 169375.61 & 189441.71 & 186621.52 \\
\hline (Gross return - Cost C3) & & & & & \\
\hline Farm Investment Income & 223456.60 & 211609.13 & 192862.50 & 211643.83 & 210261.55 \\
\hline $\begin{array}{l}\text { (Farm Business Income - Family } \\
\text { Labour wages) }\end{array}$ & & & & & \\
\hline
\end{tabular}

Table.3 Polyhouse Size wise Cost of Capsicum under Protected Conditions in Sampled Vegetable Growers (Rs.)

\begin{tabular}{|l|l|c|c|}
\hline Sr. No. & Particulars & $\mathbf{2 5 0} \mathbf{~}^{\mathbf{2}}$ & $\mathbf{5 0 0} \mathbf{~ m}^{\mathbf{2}}$ \\
\hline Cost A1 & & 1260.00 & 2292.86 \\
\hline & Human hired labour & 0.00 & 82.14 \\
\hline & Owned machinery labour & 0.00 & 142.86 \\
\hline & Hired machinery labour & 24.50 & 53.75 \\
\hline & Seed/plants & 570.00 & 1228.57 \\
\hline & FYM & 146.72 & 289.96 \\
\hline & Fertilizer & 212.70 & 720.29 \\
\hline & Plant protection & 139.41 & 278.81 \\
\hline & Depreciation & 14146.97 & 25903.51 \\
\hline & Depreciation on polyhouse & 6.00 & 6.00 \\
\hline & Land Revenue & 74.72 & 162.35 \\
\hline & Interest on working capital & $\mathbf{1 6 5 8 1 . 0 1}$ & $\mathbf{3 1 1 6 1 . 0 9}$ \\
\hline & Sub-total & $(70.35)$ & $(77.14)$ \\
\hline & & 16581.01 & 31161.09 \\
\hline Cost A2 & Cost A1 & 0.00 & 0.00 \\
\hline & Rental value of leased -in land & $\mathbf{1 6 5 8 1 . 0 1}$ & $\mathbf{3 1 1 6 1 . 0 9}$ \\
\hline & Sub-total & $(70.35)$ & $(77.14)$ \\
\hline & & 16581.01 & 31161.09 \\
\hline Cost B1 & Cost A1 & 22.19 & 44.38 \\
\hline & Interest on Fixed capital & $\mathbf{1 6 6 0 3 . 2 0}$ & $\mathbf{3 1 2 0 5 . 4 7}$ \\
\hline & Sub-total & $(70.44)$ & $(77.25)$ \\
\hline & & 16603.20 & 31205.47 \\
\hline Cost B2 & Cost B1 & 309.65 & 619.30 \\
\hline & Rental value of land & & \\
\hline
\end{tabular}




\begin{tabular}{|l|l|c|c|}
\hline & Rental value of leased -in land & 0.00 & 0.00 \\
\hline & Sub-total & $\mathbf{1 6 9 1 2 . 8 5}$ & $\mathbf{3 1 8 2 4 . 7 8}$ \\
\hline & & $(71.75)$ & $(78.79)$ \\
\hline Cost C1 & Cost B1 & 16603.20 & 31205.47 \\
\hline & Imputed value of family labour & 4515.00 & 4896.43 \\
\hline & Sub-total & $\mathbf{2 1 1 1 8 . 2 0}$ & $\mathbf{3 6 1 0 1 . 9 0}$ \\
\hline Cost C2 & Cost B2 & $(89.60)$ & $(89.38)$ \\
\hline & Imputed value of family labour & 16912.85 & 31824.78 \\
\hline & Sub-total & 4515.00 & 4896.43 \\
\hline & & $\mathbf{2 1 4 2 7 . 8 5}$ & $\mathbf{3 6 7 2 1 . 2 0}$ \\
\hline Cost C3 & Cost C2 & $(90.91)$ & $(90.91)$ \\
\hline & Value of management input(10\% of cost C2) & 21427.85 & 36721.20 \\
\hline & Sub-total & $\mathbf{2 3 5 7 0 . 6 4}$ & 3672.12 \\
\hline & & $\mathbf{4 0 3 9 3 . 3 2}$ \\
\hline & & $(100.00)$ & $(100.00)$ \\
\hline
\end{tabular}

Table.4 Polyhouse Size wise Return from Capsicum under Protected Conditions in Sampled Vegetable Growers (Rs.)

\begin{tabular}{|c|c|c|}
\hline Particulars & $250 \mathrm{~m}^{2}$ & $500 \mathrm{~m}^{2}$ \\
\hline Yield of Capsicum (qtls.) & 14.20 & 32.68 \\
\hline Gross Return & 28400.00 & 65357.14 \\
\hline Farm Business Income & 11818.99 & 34196.05 \\
\hline \multicolumn{3}{|l|}{ (Gross return - Cost A1) } \\
\hline Family Labour income & 11487.15 & 33532.37 \\
\hline \multicolumn{3}{|l|}{ (Gross return - Cost B2) } \\
\hline Farm Income (net income) & 4829.36 & 24963.82 \\
\hline \multicolumn{3}{|l|}{ (Gross return - Cost C3) } \\
\hline Farm Investment Income & 7303.99 & 29299.62 \\
\hline (Farm Business Income - Family Labour wages) & & \\
\hline
\end{tabular}

Table.5 Comparative Cost and Return Analysis of Capsicum under Protected and Open Field Conditions in Sampled Vegetable Growers (Rs.)

\begin{tabular}{|l|c|c|c|c|}
\hline \multirow{2}{*}{ Particulars } & \multicolumn{2}{|c|}{$\mathbf{2 5 0} \mathbf{~ m}^{\mathbf{2}}$} & \multicolumn{2}{c|}{$\mathbf{5 0 0} \mathbf{~ m}^{\mathbf{2}}$} \\
\hline Cost of cultivation & Protected & Open & Protected & Open \\
\hline Gross return & 23570.64 & 2815.01 & 40393.32 & 5623.42 \\
\hline Net Return & 28400.00 & 7397.43 & 65357.14 & 14794.86 \\
\hline Break-even point & 4829.36 & 4582.42 & 24963.82 & 9171.44 \\
\hline Margin of safety & 21349.68 & 1989.22 & 33869.39 & 3965.99 \\
\hline Margin of safety (\%) & 7050.32 & 5408.21 & 31487.75 & 10828.87 \\
\hline
\end{tabular}


Fig.1 Comparative economics of capsicum production under protected and open field conditions in $250 \mathrm{~m}^{2}$ area

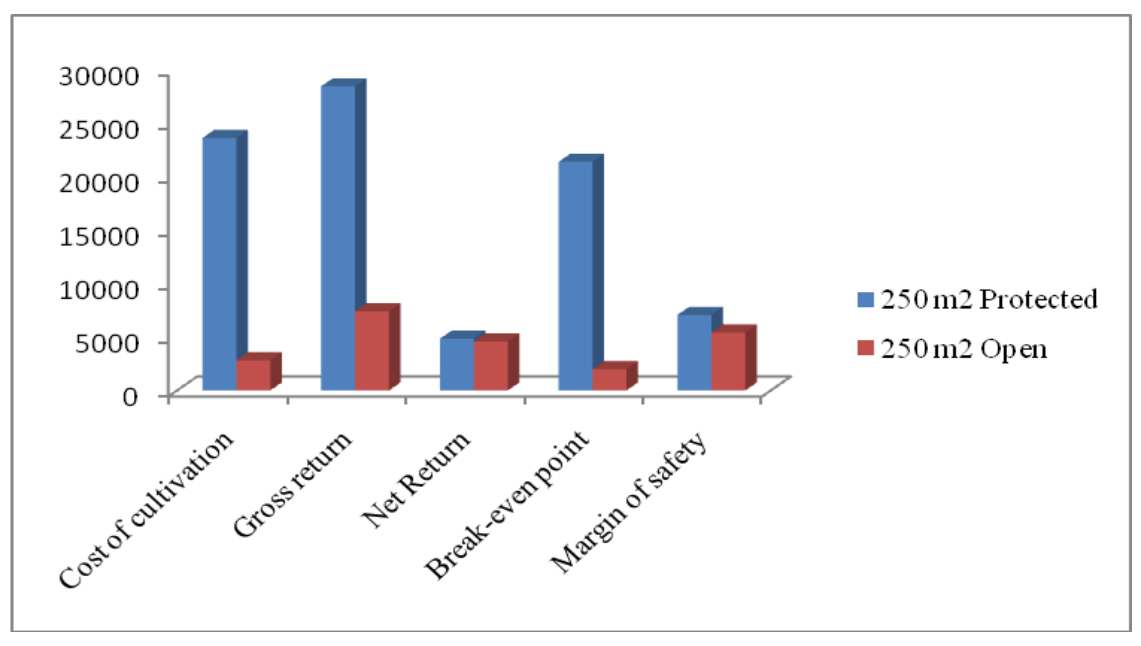

Fig.2 Comparative economics of capsicum production under protected and open field conditions in $500 \mathrm{~m}^{2}$ area

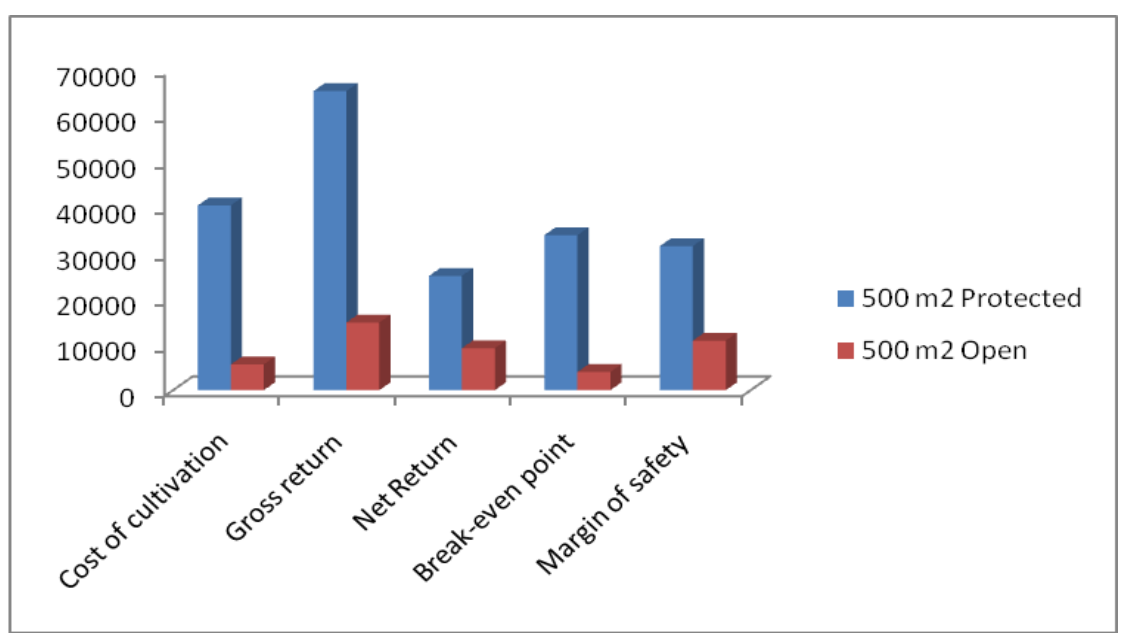

The gross return and net return of capsicum under protected conditions were Rs. 28400.00 and Rs. 4829.36 respectively while in case open conditions, gross return and net return of capsicum were Rs. 7397.43 and Rs. 4582.42 respectively. The break-even point and margin of safety for capsicum under protected conditions were Rs. 21349.68 and Rs. 7050.32 which was comparatively higher than open conditions. Percent margin of safety under protected conditions was 75.17 percent while it was 26.89 percent in open conditions (fig. 1).
In case of $500 \mathrm{~m}^{2}$, the cost of cultivation of capsicum under protected conditions was also much higher (Rs. 40393.32) than open conditions (Rs. 5623.42). The gross return and net return of capsicum under protected conditions were Rs. 65357.14 and Rs. 24963.82 respectively while in case open conditions, gross return and net return of capsicum were Rs. 14794.86 and Rs. 9171.44 respectively. The break-even point and margin of safety for capsicum under protected conditions were Rs. 33869.39 and Rs. 31487.75 which was comparatively higher 
than open conditions (fig. 2). Percent margin of safety under protected conditions was 51.82 percent while in open conditions it was 26.81 percent. It implies protected cultivation has less risk of failure of farm business over open field conditions. Similar findings were also reported by Nagalakshmi et al., (2001) and Sreedhara et al., (2013), Kumar et al., (2016).

In conclusion the present study concluded that the cost of production of capsicum under open conditions was Rs. 113878.48 per hectare at overall level and varied between Rs. 118695.63 to Rs. 128959.10 per hectare among different farm categories. The net returns varied between Rs. 169375.61 to Rs. 198475.11 among different farm categories with an average return of Rs. 186621.52 at overall level. Farm investment income varied between Rs. 192862.50 to Rs. 223456.60 with Rs. 210261.55 at overall level. The cost of production of capsicum under protected conditions was Rs. 23570.64 and Rs. 40393.32 in $250 \mathrm{~m}^{2}$ and $500 \mathrm{~m}^{2}$ polyhouse respectively. Net returns were Rs. 4829.36 and Rs. 24963.82 in $250 \mathrm{~m}^{2}$ and $500 \mathrm{~m}^{2}$ polyhouse respectively. Farm investment income was Rs. 7303.99 and Rs. 29299.62 in $250 \mathrm{~m}^{2}$ and $500 \mathrm{~m}^{2}$ polyhouse respectively. the cost of cultivation in polyhouse cultivation was Rs. $20755.63 / 250 \mathrm{~m}^{2}$ and Rs. $34769.90 / 500 \mathrm{~m}^{2}$ more than from open field cultivation. The gross returns from polyhouse cultivation worked out Rs. $21002.57 / 250 \mathrm{~m}^{2}$ and Rs. 50.562.28/500 $\mathrm{m}^{2}$ more as compared to open field cultivation and net returns from polyhouse are Rs. $246.94 / 250 \mathrm{~m}^{2}$ and Rs. $15792.38 / 500 \mathrm{~m}^{2}$ more than open cultivation of capsicum. The break-even point in polyhouse cultivation was Rs. 21349.68/250 $\mathrm{m}^{2}$ and Rs. $33869.39 / 500 \mathrm{~m}^{2}$ while in open cultivation, it was only Rs. $1989.22 / 250 \mathrm{~m}^{2}$ and Rs. $3965.99 / 500 \mathrm{~m}^{2}$ and margin of safety was Rs. 1642.11/250 $\mathrm{m}^{2}$ and Rs. $20658.88 / 500 \mathrm{~m}^{2}$ more than open cultivation.
Per cent margin of safety was very high $\left(75.17 \& 51.82\right.$ in $250 \mathrm{~m}^{2}$ and $500 \mathrm{~m}^{2}$ respectively) as compared to open cultivation of capsicum (26.89\& 26.81 in $250 \mathrm{~m}^{2}$ and $500 \mathrm{~m}^{2}$ respectively).

\section{References}

Chadha, K. L. 2005. Handbook of Horticulture. 368-371.

Bala, B., Sharma, N. and Sharma, R. K. 2011. Cost and return structure for the promising enterprise of off season vegetables in Himachal Pradesh. Agricultural Economics Research Review. 24:141-148.

Baruwa, O.I. and Adesina, C.A. 2013. Economics of leafy vegetable production. International Journal of Vegetable Science. 19:21-25.

Bhargava, B., Gupta, Y.C. and Sharma, P. 2014. Performance of Snapdragon (Antirrhinum majus L) under protected and open field conditions in Himachal Pradesh. Proceedings of the National Academy of Sciences, India Section B: Biological Sciences. 86:65-69.

Chattha, M.R., Imran, M., Khan, M.A., Ali, A., Anjum, A.S., Iftkhar, M., Jved, M.A. and Kasana, I. 2015. Comparative study and economics of different vegetables organically grown under tunnel and open field conditions. International Journal of Biological Biotechnology. 12:233-236.

Dhandare, K.M., Singh, K.K., Singh, P.K., Singh, M.P. and Gonfa, Bayissa. 2007. Response of capsicum (Capsicum annuum L.) under cyclic irrigation in polyhouse condition. Pantnagar Journal of Research. 5:135-138.

Singh, R. and Asrey, R. 2005. Performance of tomato and sweet pepper under unheated green house. Haryana Journal of Horticulture Science. 34:174

Singh, V.P., Singh, R.P., Godara, A.K., 
Malik, T.P., Arora, S.K. and Mehra, R. 2007. Performance of Capsicum cultivars under naturally ventilated polyhouse environment. Haryana Journal of Horticultural Sciences. 36:307.

Sreedhara, D.S., Kerutagi, M.G., Basavaraja, H., Kunnal, L.B. and Dodamani, M.T. 2013. Economics of capsicum production under protected conditions in Northern Karnataka. Karnataka Journal of Agricultural Science. 26:217219.

Sreedhara, D.S. 2010. Comparative economics of capsicum production under protected and open conditions in Northern Karnataka. M.Sc. Thesis. Agricultural Economics (Department), University of Agricultural Sciences, Dharwad.

Heiser, C. B. and Smith, P. G. 1953. The cultivated capsicum peppers. Economic Botany.7:214-27.

Joshi, A. and Shukla, Y. R. 1997. Diversification of vegetable crop in the temperate region of India. A Model Punjab Vegetable Grower. 32: 24-27.
Kumar, P., Chauhan, R.S., Grover, R.K. 2016. Economic analysis of capsicum cultivation under polyhouse and open field condition in Haryana. International Journal of Farm Sciences. 6:96-100

Nagalakshmi, S., Nandakumar, N., Palanisamy, D. and Sreenarayanan, V.V. 2001. Naturally ventilated polyhouse for vegetable cultivation. South Indian Horticulture. 49: 345-346.

NHB.2015. Final area and production estimates for horticulture crops for 2015-16.

http://www.nhb.gov.in/area\%20-

production.html. National Horticulture Board, Gurgaon.

Peirce, L. C. 1987.Vegetable Characteristics, Production and Marketing.New York, John Wiley and Sons. 325p.

Sreedhara, D.S., Kerutagi, M.G., Basavaraja, H., Kunnal, L.B. and Dodamani, M.T. 2013. Economics of capsicum production under protected conditions in northern Karnataka. Karnataka Journal of Agricultural Sciences. 26(2): 217-219.

\section{How to cite this article:}

Navneet Singh, Ravinder Sharma and Ratika Kayastha. 2020. Comparative Economics Analysis of Capsicum Cultivation under Protected and Open Field Conditions in Himachal Pradesh. Int.J.Curr.Microbiol.App.Sci. 9(08): 1002-1012. doi: https://doi.org/10.20546/ijcmas.2020.908.109 